\title{
Biofilm formation by the yeast Rhodotorula mucilaginosa: process, repeatability and cell attachment in a continuous biofilm reactor
}

Jasmin Gattlen, Manfred Zinn, Sébastien Guimond, Enrico Körner , Caroline Amberg \& Laurie Mauclaire

To cite this article: Jasmin Gattlen, Manfred Zinn, Sébastien Guimond, Enrico Körner , Caroline Amberg \& Laurie Mauclaire (2011) Biofilm formation by the yeast Rhodotorula mucilaginosa:

process, repeatability and cell attachment in a continuous biofilm reactor, Biofouling, 27:9, 979-991, DOI: 10.1080/08927014.2011.619657

To link to this article: https://doi.org/10.1080/08927014.2011.619657

\section{Published online: 07 Oct 2011.}

Submit your article to this journal $2 \pi$

Џll Article views: 274

Q View related articles $\square$

4 Citing articles: 3 View citing articles 


\title{
Biofilm formation by the yeast Rhodotorula mucilaginosa: process, repeatability and cell attachment in a continuous biofilm reactor
}

\author{
Jasmin Gattlen ${ }^{\mathrm{a}}$, Manfred Zinn*, Sébastien Guimond ${ }^{\mathrm{b}}$, Enrico Körner ${ }^{\mathrm{b}}$, Caroline Amberg ${ }^{\mathrm{c}}$ and Laurie Mauclaire \\ ${ }^{a}$ Empa, Swiss Federal Laboratories for Materials Science and Technology, Laboratory for Biomaterials, Lerchenfeldstrasse 5, \\ CH-9014 St. Gallen, Switzerland; ${ }^{b}$ Empa, Swiss Federal Laboratories for Materials Science and Technology, Laboratory for \\ Advanced Fibers, Lerchenfeldstrasse 5, CH-9014 St. Gallen, Switzerland; ' Empa Testmaterials AG, Moevenstrasse 12, CH-9015 St. \\ Gallen, Switzerland
}

(Received 10 August 2011; final version received 30 August 2011)

\begin{abstract}
Yeast biofilms contribute to quality impairment of industrial processes and also play an important role in clinical infections. Little is known about biofilm formation and their treatment. The aim of this study was to establish a multi-layer yeast biofilm model using a modified 3.71 bench-top bioreactor operated in continuous mode $\left(\mathrm{D}=0.12 \mathrm{~h}^{-1}\right)$. The repeatability of biofilm formation was tested by comparing five bioprocesses with Rhodotorula mucilaginosa, a strain isolated from washing machines. The amount of biofilm formed after 6 days post inoculation was $83 \mu \mathrm{g} \mathrm{cm}^{-2}$ protein, $197 \mu \mathrm{g} \mathrm{cm}^{-2}$ polysaccharide and $6.9 \times 10^{6} \mathrm{CFU} \mathrm{cm}^{-2}$ on smooth polypropylene surfaces. Roughening the surface doubled the amount of biofilm but also increased its spatial variability. Plasma modification of polypropylene significantly reduced the hydrophobicity but did not enhance cell attachment. The biofilm formed on polypropylene coupons could be used for sanitation studies.
\end{abstract}

Keywords: yeast; Rhodotorula mucilaginosa; model biofilm; test system; bioprocess

\section{Introduction}

The wealth of information on the development, structure and impact of bacterial biofilms in different fields such as medicine, biotechnology or ecology is enormous. In comparison, knowledge about fungal biofilms (both yeast and filamentous fungi) is still in its infancy.

Yeast biofilm development is similar to that of bacteria (Harding et al. 2009). The phases of biofilm formation such as adherence, microcolony formation, maturation, biofilm maintenance and dispersal occur (Harding et al. 2009). The main difference in biofilm development is the morphological transition of some yeast cells during maturation. Dimorphic yeasts, like Candida albicans and Saccharomyces cerevisiae, attach to the surface and build a monolayer as spherical cells and pseudohyphae during maturation (Vopalenska et al. 2010). Rhodotorula sp. also has the ability to form pseudohyphae but their formation has not been reported during biofilm formation. For the examination of cell attachment, biofilm growth and production reactors such as perfusion chambers (Palmer 1999), modified Robbins devices (Kharazmi et al. 1999) or rotating disk reactors (Hentzer et al. 2001) were used. These systems focused on bacterial biofilm, whereas few studies with yeast cells have been performed
(Busscher et al. 1994). From a practical point of view yeasts are more complicated to cultivate than bacteria because of a rather slow growth and a higher susceptibility to contamination by bacteria (Saithong et al. 2009) or other yeasts (Kronlof and Haikara 1991). Yeast can grow directly on plastics (Reynolds and Fink 2001) or stainless steel (Brugnoni et al. 2007) but also on bacterial (Jenkinson and Douglas 2002) or fungal biofilms (Webb et al. 2000) as a secondary colonizer.

Biofilm comprised of yeast occurs not only on implants (Douglas 2002) but also on industrially relevant devices such as photo-processing tanks (Elvers et al. 1998) and food processing plants (Brugnoni et al. 2007) where yeast biofilms influence the quality and taste of the product. They are also found in domestic environments such as kitchen sponges, dish towels (Rayner et al. 2004) or household washing machines (Gattlen et al. 2010). Biofilms in household washing machines produce malodor and impair hygienic performance due to increased use of low-temperature and bleach-free washing (Munk et al. 2001). In industry, biofilms lead to costs of several billion dollars every year due to eg product losses (Kumar and Anand 1998), reduced heat transfer (Shi and Zhu 2009), increased fuel consumption (Chambers et al. 2006) and

\footnotetext{
*Corresponding author. Email: manfred.zinn@empa.ch 
the use of chemical agents for control and removal of biofilms (Lyon et al. 2008). Besides chemicals (eg antimicrobial agents), several mechanical strategies are available to remove biofilms (eg ultrasound) (Muller et al. 2007). However, treatment efficiency (especially of antimicrobial agents) for biofilms remains unclear because there are still very few test systems available to evaluate biofilm removal (Hamilton 2002; Pitts et al. 2003; Bloss and Kampf 2004). One reason why biofilm removal cannot be efficiently quantified is the lack of reference biofilms. Such reference material should represent the system of interest and be produced in a repeatable manner. Short-term studies of antimicrobial and biofilm removal tests can be performed in 96-well plates for bacteria (Pitts et al. 2003) and yeasts (Rambali et al. 2001). Chandra et al. (2001) produced a 24 h-old $C$. albicans model biofilm on prosthesis material cultivated in 12-well tissue culture plates for testing antifungal agents. Ramage et al. (2001) developed a high throughput 96-well plate system to produce and study $C$. albicans biofilms. However, all these biofilms were cultivated in well plates. The cultivation of biofilms in well plates is limited to young biofilms (24-48 h old) because continuous nutrient supply is not possible. Therefore, they are not representative of thicker and/or older (initially mature) (Harding et al. 2009) or mature biofilms as they are typically found in industrial plants or home appliances. An alternative to study initially mature biofilms is the use of bioreactors. This was successfully done for bacterial biofilms using either rotating disk reactors (Pitts et al. 2001) or a reactor developed by the Centers for Disease Control (CDC reactor) (Goeres et al. 2005; Hadi et al. 2010).

Available yeast models that are not used for testing antimicrobial susceptibility focus more on the developmental characteristics of biofilm formation (Ramage et al. 2001). A laminar flow or biofilm bioreactor system is more convenient for the study of initially mature biofilms because flow systems can be adjusted to represent particular physiological conditions (eg nutrient limitations and different shear stress) better than well plates.

A further aspect for the development of a model biofilm is that the resulting biofilm is repeatable and reproducible (eg amount of cells, total protein). Repeatable biofilm formation has already been successfully achieved with bacteria grown in rotating disk reactors (Pitts et al. 2001), rotating annular reactors (Chen and Stewart 2000) and in the CDC reactor to evaluate the effects of chemical agents (Goeres et al. 2005; Hadi et al. 2010). First attempts to grow $C$. albicans in a CDC reactor were described by Honraet et al. (2005), where the main goal was to test different quantification techniques rather than producing a model biofilm.
However, yeast model biofilms have not been produced in a comparable reactor system which would allow the reproducible production of biofouled test coupons. Such standardized biofilms could be of use for testing the removal efficiency of cleaning and sanitation (either mechanical or with antimicrobial and chemical agents). Further, they could be applied for testing tolerance towards detergents or antimicrobial agents as well as dosage effects. The potential field of applications could be medical devices but also water pipes (either cooling or water distribution systems) and manufacturing procedures (eg plate heat exchanger of pasteurizers for diary processing).

The goal of this study was to establish a model yeast biofilm to be used as reference for testing removal efficiency of household washing machines (Gattlen et al. 2010). The yeast Rhodotorula mucilaginosa that was originally isolated from household washing machines was chosen as model organism. $R$. mucilaginosa was grown in a modified bench-top reactor to firstly determine the cultivation conditions in minimal medium for the optimal production of a multi-layered yeast biofilm and secondly, to assess repeatable biofilm formation on polypropylene coupons with different surface characteristics (smooth and rough, as well as plasma treated).

\section{Material and methods}

\section{Bioreactor set-up}

For the experiment a modified 3.71 bench-top bioreactor (KLF2000, Bioengineering AG, Wald, Switzerland) was used (Figure 1). A stainless steel cylinder (height: $20 \mathrm{~cm}$, maximal diameter: $6 \mathrm{~cm}$ ) designed to hold six removable coupon holders (stainless steel) with space for 20 test coupons was mounted on the stirrer axis replacing the stirrer blades. The coupons were immersed in $70 \%$ ethanol $(\mathrm{EtOH})$ and sonified in a water bath for at least 10 min before mounting into the metal holders for chemically cleaning the coupon surfaces. In order not to modify the surface, ethanol was chosen for cleaning. Autoclaving sterilizes the surface but is not able to remove grease. The test coupons were used only once. A pH probe (RedCap 405-60-T-S7/120/9848, Mettler Toledo, Greifensee, Switzerland) was calibrated with two reference solutions with $\mathrm{pH}=4$ and $\mathrm{pH}=7$ (BioChemika). An external aeration loop was connected to the reactor to avoid bubble formation that could result in additional shear force and remove biofilm from test coupons. A trap column for liquids was connected between the 501 medium bag and the reactor to prevent back contamination of the medium bag.

The biofilm reactor was filled with $2.5130 \%$ Sabouraud dextrose broth (SDB, $\mathrm{pH}=5.6$ ) to control 


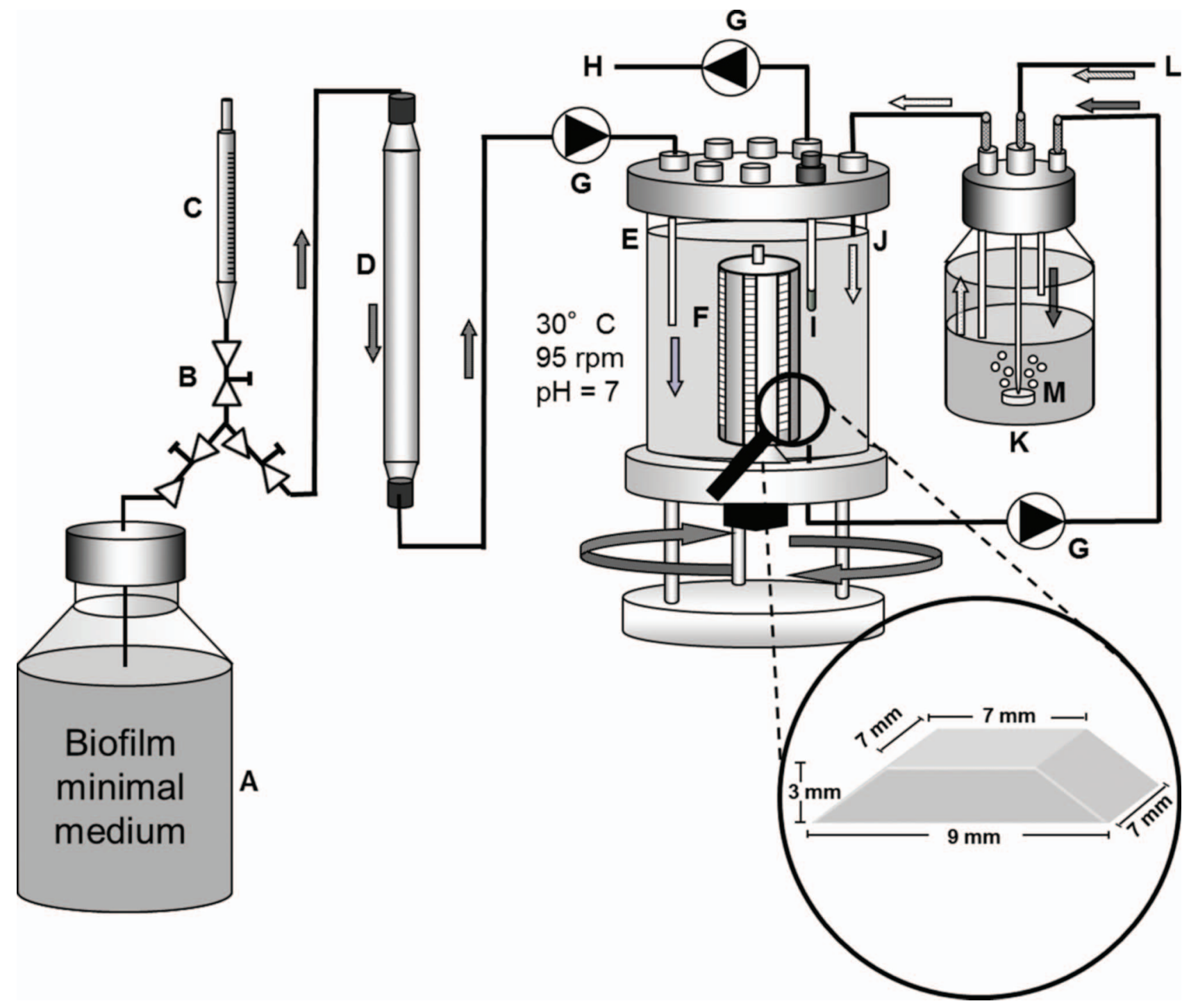

Figure 1. Set up of reactor system for biofilm formation. A: medium reservoir (50 1) with biofilm minimal medium, B: valve, C: glass burette for flow measurements, D: glass column for prevention of back contamination, E: submerged inlet tube for biofilm minimal medium feed, F: rotating cylinder with coupons, G: peristaltic pumps, H: outlet waste, I: pH meter, J: inlet of aerated medium, K: aeration bottle, L: inlet for pressurized air, M: ventilation frit, magnification of the trapezoid PP coupons. Biofilm formation of coupon occurred only on the top surface $(7 \times 7 \mathrm{~mm})$.

and slow down cell growth as well as to adjust the cells to a poor nutritional environment as will follow during continuous cultivation. The medium was sterilized ( $30 \mathrm{~min}$ at $\left.121^{\circ} \mathrm{C}\right)$. The external aeration bottle filled with $c a 500 \mathrm{ml}$ of $30 \%$ SDB (Figure $1 \mathrm{~K}$ ), the whole tubing system as well as the glass columns (see Figure1C,D) were autoclaved separately. The aeration of the biofilm reactor via external aeration loop (Figure $1 \mathrm{~K}$ ) was initiated $c a 12-15 \mathrm{~h}$ prior to inoculation to stabilize the system and ensure sufficient dissolved oxygen tension during inoculation. The cyclic flow in the aeration loop was maintained by a peristaltic pump (Periplex, Bioengineering AG) (Figure 1G) running at maximum speed and an overpressure triggered by the aeration of filtered air via a ventilation frit (Figure 1M).

\section{Characterization of test coupon material}

$P P$ composition and surface roughness

The supporting material for biofilm formation was white polypropylene (PP) reinforced with glass fibers (Lot Nr.: PP Miele Granulate Hostacom EKG W92535, Germany). The PP plates were cut to trapezoid coupons (top surface $7 \mathrm{~mm} \times 7 \mathrm{~mm}$, bottom surface: $7 \mathrm{~mm} \times 9 \mathrm{~mm}$, thickness: $3 \mathrm{~mm}$ ) (Figure 1) and either used unchanged or with a roughened top surface with a sandpaper/abrasive paper (150 grains 
$\mathrm{cm}^{-2}$ ), perpendicular to the direction of rotation in the reactor. Alternatively, a set of dye-casted PP (dcPP) with a defined roughness (roughness 24, defined according to VDI 3400; Treff AG, Degersheim, Switzerland) was used to examine the influence of the coupon material on biofilm formation. The composition of the dcPP was similar to the PP provided by Miele, however, without glass-fibres and zinc oxide (white color) as additives.

\section{Plasma treatment of coupons}

To reduce the hydrophobic nature of the dcPP coupons, they were plasma activated or plasma coated using the following gases and gas mixtures: $\mathrm{Ar} / \mathrm{O}_{2}, \mathrm{~N}_{2}$, $\mathrm{NH}_{3} / \mathrm{C}_{2} \mathrm{H}_{4}$ (ratios $1: 1$ and 2:1) and $\mathrm{CO}_{2} / \mathrm{C}_{2} \mathrm{H}_{4}$ (ratios 2:1 and 6:1). The $\mathrm{C}_{2} \mathrm{H}_{4}$ based gas mixtures led to the deposition of plasma polymer thin films where either $\mathrm{N}$ - or O-containing functional groups were embedded. The functional groups based on $\mathrm{N}_{2}$ and $\mathrm{Ar} / \mathrm{O}_{2}$ were directly grafted onto the PP surface. The exact procedure was carried out as described elsewhere (Hegemann et al. 2007; Hossain et al. 2007; Koerner et al. 2009). Prior to reactor experiments the coatings were tested for heat stability $\left(121^{\circ} \mathrm{C}\right.$, in the presence of culture broth). The composition of the coupon surface was characterized by X-ray photoelectron spectroscopy (XPS; PHI 5600 spectrometer, USA, $n=1$ ) and static contact angle measurements using a droplet of distilled water $(\sim 5 \mu \mathrm{l})(n=3)$. A set of 18 coated coupons (three coupons for each plasma coating condition) was autoclaved in the presence of $30 \%$ SDB to simulate the conditions within the reactor during medium sterilization and to check the influence of the culture medium on the plasma-coating. The samples were air-dried under laminar flow in the sterile bench for $2.5 \mathrm{~h}$ and contact angles were measured (Krüss G10 apparatus, Hamburg, Germany). In order to evaluate the stability of the functionalization after 2 days, the samples were dipped for $30 \mathrm{~s}$ in nanopure water, dried for $2.5 \mathrm{~h}$ and water contact angles were measured again. Freshly coated coupons were used for cultivation experiments.

\section{Cultivation of the yeast $\mathrm{R}$. mucilaginosa}

$R$. mucilaginosa, a pigmented yeast typically living in terrestrial and aqueous habitats, was isolated from a household washing machine (Gattlen et al. 2010) and was used throughout all experiments.

\section{Preparation of frozen stocks}

Since frozen stocks are a potential source of variability, the preparation of the stocks was performed with special care. A colony of $R$. mucilaginosa grown on Sabouraud $4 \%$ glucose agar (SDA) was transferred into $15 \mathrm{ml}$ of SDB and incubated for $c a 18 \mathrm{~h}\left(30^{\circ} \mathrm{C}\right.$, $150 \mathrm{rpm}$ ). The culture was used to inoculate a shake flask containing $100 \mathrm{ml}$ of SDB. The cells were grown $\left(150 \mathrm{rpm}, 30^{\circ} \mathrm{C}\right)$ until an $\mathrm{OD}_{600}$ of about $0.5-1.0$ was reached. The culture broth was mixed $1: 1\left(\mathrm{v} \mathrm{v}^{-1}\right)$ with $30 \%$ glycerol and $2 \mathrm{ml}$ aliquots were prepared. Cells were frozen at $-20^{\circ} \mathrm{C}$ overnight and stored at $-80^{\circ} \mathrm{C}$ until usage.

\section{Preparation of pre-cultures}

For the preparation of the bioreactor inoculum one vial with frozen yeast cells $(2 \mathrm{ml})$ was transferred into a baffled shake flask containing $150 \mathrm{ml}$ of SDB supplemented with anhydrous ampicillin (final concentration: $50 \mu \mathrm{g} \mathrm{ml}^{-1}$ ) and chloramphenicol (final concentration: $500 \mu \mathrm{g} \mathrm{ml}^{-1}$ ). Antibiotics were used to prevent contamination with bacteria. Cells were incubated at $30^{\circ} \mathrm{C}, 150 \mathrm{rpm}$ for $c a 24 \mathrm{~h}$ until reaching an optical density of $2.6 \pm 0.1$.

\section{Inoculation of the bioreactor}

Cells reaching the late exponential phase were inoculated into the biofilm reactor at $30^{\circ} \mathrm{C}$ and a cylinder rotation of $95 \mathrm{rpm}$. Cell growth was followed by measurements of $\mathrm{OD}_{600}$. When the maximal growth rate $\mu_{\max }\left(0.23-0.27 \mathrm{~h}^{-1}\right)$ was reached the washout of cells in suspension was initiated. In order to wash out the non-adhering cells, continuous cultivation was started with an initial dilution rate of $c a 0.52 \mathrm{~h}^{-1}$ with biofilm minimal medium. The biofilm minimal medium $(\mathrm{pH}=7)$ for continuous cultivation consisted of $1 \mathrm{~g}$ $1^{-1} 3$-(N-morpholino)propanesulfonic acid (MOPS), $1.1 \mathrm{~g} \mathrm{l}^{-1}\left(\mathrm{NH}_{4}\right)_{2} \mathrm{SO}_{4}, 0.15 \mathrm{~g}^{-1} \mathrm{KH}_{2} \mathrm{PO}_{4}, 0.25 \mathrm{~g}^{-1}$ $\mathrm{MgSO}_{4} \times 7 \mathrm{H}_{2} \mathrm{O}, 0.1 \mathrm{~g} \mathrm{l}^{-1} \mathrm{FeSO}_{4} \times 7 \mathrm{H}_{2} \mathrm{O}, 0.2 \mathrm{~g}$ $\mathrm{L}^{-1}$ ethylenediaminetetraacetic acid disodium salt and $1 \mathrm{ml}$ of filter-sterilized $(0.22 \mu \mathrm{m}$, Milex, Milipore AG, Zug, Switzerland) trace element stock solution $\left(1.5 \mathrm{~g} \mathrm{l}^{-1} \mathrm{CaCl}_{2} \times 2 \mathrm{H}_{2} \mathrm{O}, 3.96 \mathrm{~g} \mathrm{l}^{-1} \mathrm{MnCl}_{2} \times 4 \mathrm{H}_{2} \mathrm{O}\right.$, $5.62 \mathrm{~g} \mathrm{l}^{-1} \mathrm{CoSO}_{4} \times 7 \mathrm{H}_{2} \mathrm{O}, 0.34 \mathrm{~g} \mathrm{l}^{-1} \mathrm{CuCl}_{2} \times 2$ $\mathrm{H}_{2} \mathrm{O}, 1 \mathrm{~g} \mathrm{l}^{-1} \mathrm{ZnSO}_{4} \times 7 \mathrm{H}_{2} \mathrm{O}, 1 \mathrm{~g}^{-1} \mathrm{MoO}_{4} \mathrm{Na}_{2} \times$ $2 \mathrm{H}_{2} \mathrm{O}, \mathrm{pH}=1$ ) with $4 \mathrm{~g}^{-1}$ glycerol as carbon source. All chemicals (Sigma-Aldrich, Buchs, Switzerland) except for the micronutrient solution were autoclaved prior to filter-sterilization $(0.45 \mu \mathrm{m}+0.2 \mu \mathrm{m}$; Sartorius) to minimize risk of contamination. In previous experiments it has been observed that filter-sterilization was not sufficient to remove contaminants from the chemicals. The dilution rate was set twice as high as the $\mu_{\max }$ to wash out non-adhering cells for $13 \pm 1 \mathrm{~h}$. After washout the dilution rate was reduced to $0.12 \mathrm{~h}^{-1}$ for further cultivation. 


\section{Sampling and quantification of biofilms}

Biofilm formation was assessed on PP coupons mounted in holders on a rotating cylinder (Figure 1). For the temporal development of biofilm formation, one holder harbouring 14 test coupons ( 7 rough and 7 smooth) was harvested after 1, 3, 6, 9, and 13 days post inoculation. One smooth and one rough coupon were prepared for microscopic observation by confocal laser scanning microscopy (CLSM).

For the repeatability test, all six holders of a bioreactor numbering 16-23 smooth and 18 rough coupons were sampled for biofilm quantification on day 6 . The remaining coupons were only used to fill the other positions.

The plasma treated coupons were harvested after 1 , 3 and 6 days post inoculation and biofilm was quantified $(n=4)$ as follows.

\section{Sampling of coupons}

After removal from the holder unit, each coupon was briefly submerged in sterile $0.9 \% \mathrm{NaCl}$ solution to remove loosely attached cells. Each coupon was then transferred into $5 \mathrm{ml}$ of $0.9 \% \mathrm{NaCl}$ and treated with ultrasound (sonifier tip, Branson sonifier) at $0^{\circ} \mathrm{C}(10 \%$ amplitude, $30 \mathrm{~s}$ with alternating $1 \mathrm{~s}$ pulse on and $1 \mathrm{~s}$ pulse off) to detach the cells from the coupon. The suspensions were stored at $4^{\circ} \mathrm{C}$ for a maximum of $4 \mathrm{~h}$ due to the large number of samples that needed to be sonified. The samples were vortexed before subsampling for further analysis.

\section{Optical density}

One $\mathrm{ml}$ of cell suspension derived from sonified biofilms was measured with a spectrophotometer (Spectronic ${ }^{\circledR}$ Genesys ${ }^{\mathrm{TM}}$ 6, UV-visible spectrophotometer, Thermo Electron Schweiz AG, Allschwil, Switzerland) at $600 \mathrm{~nm}$.

\section{Polysaccharide quantification}

This was based on Dubois et al. (1956). Because the main constituents of the EPS matrix are polysaccharides the total amount of polysaccharide was quantified (Sutherland 2001; Flemming and Wingender 2010). One $\mathrm{ml}$ of cell suspension was taken, $25 \mu \mathrm{l}$ of $80 \%$ (v $\mathrm{v}^{-1}$ ) phenol dissolved in distilled water were added and the sample was vortexed. Subsequently, $2.5 \mathrm{ml}$ of 98\% sulphuric acid (Merck, Zug, Switzerland) were added within $20-30 \mathrm{~s}$ in the center of the solution to ensure perfect mixing, followed by vortexing for $1 \mathrm{~min}$, cooling at room temperature for $10 \mathrm{~min}$, vortexing again and finally incubating in the water bath at $26 \pm 1^{\circ} \mathrm{C}$ for $20 \mathrm{~min}$. Before reading the light absorption at $485 \mathrm{~nm}$, the samples were vortexed again. A standard curve was prepared with $\mathrm{D}(+)-$ glucose dissolved in distilled water $\left(0-35 \mu \mathrm{g} \mathrm{ml}^{-1}\right)$. Samples containing sugar concentrations $>35 \mu \mathrm{g}$ $\mathrm{ml}^{-1}$ glucose equivalents were diluted with $0.9 \%$ $\mathrm{NaCl}$ and re-analysed.

\section{Protein quantification}

Proteins are a large component of the microbial cell and also found in the matrix consisting of exopolymeric substances (EPS) (Sutherland 2001), therefore the total amount of protein was analysed. For the quantification of the total protein, the micro BCA protein assay kit (Thermo Scientific, Rockford Illinois, USA), based on the biuret reaction, was applied according to manufacturer's instructions. A standard curve was prepared with BSA $(0-40 \mu \mathrm{g}$ $\mathrm{ml}^{-1}$ ).

\section{Viable cell counts}

Viable cell counts by colony forming units (CFU) were performed by serial dilutions of the suspension and plating on SDA plates. The plates were incubated for ca 2 days at $30^{\circ} \mathrm{C}$ before counting.

\section{Confocal laser scanning microscopy}

Sampled coupons were placed on wet paper and kept under humid atmosphere at $4{ }^{\circ} \mathrm{C}$ for no longer than $5 \mathrm{~h}$ before staining. The coupons were stained for 30 min in the dark with $100 \mu \mathrm{l}$ of a mixture of $0.1 \mathrm{M}$ Tris buffer $(\mathrm{pH}=7.5)$ and Syto BC (Molecular Probes, Invitrogen, Lucerne, Switzerland, final concentration: $0.5 \mu \mathrm{M})$ for staining cell DNA. ConcanavalinAlexa-633 (Molecular Probes, Invitrogen, final concentration: $0.1 \mathrm{mg} \mathrm{ml}^{-1}$ ) was used for staining lectins of the EPS sugar residues of the biofilm matrix.

The cells were examined with a confocal laser scanning microscope (Axioplan 2 Imaging LSM 510, Zeiss) at wavelength of 488 and $632 \mathrm{~nm}$ for Syto BC and ConcanavalinAlexa-633, respectively. The micrographs were recorded and analyzed with the LSM Image examiner (Zeiss, version 4.0.0.2).

\section{Statistical analysis of samples}

In general, the mean values and standard deviations (SDs) for the $\mathrm{OD}_{600}$, polysaccharide, protein and viable cell counts were determined for each sampling day. An exception was the first experiment of the repeatability tests where neither cell number nor polysaccharide quantification was done. 


\section{Determination of the repeatability of the bioprocess}

\section{Spatial variability within the bioreactor}

Data sets for each parameter of all five experiments with smooth and rough coupons were checked for normal distribution using Kolmogorov-Smirnov $(\alpha=0.05)$. It is essential for ANOVA-2 analysis that the sample size for each reactor experiment is the same. In case a coupon was lost during harvesting and consequently no data could be obtained, the mean of the samples with the same position on other holders in the reactor was taken as a value. However, this procedure had to be done only in the case of three coupons, two smooth and one rough.

To determine the homogeneity of the growth conditions along the vertical axis, one holder of each reactor experiment was analysed from top to bottom (position 4 to 18) for smooth and rough coupons ( $n=3-7$ and 3 , respectively). The presence of a vertical gradient was tested using the linear regression model $(\alpha=0.05)$. For regression analysis outliers were determined applying the Grubbs test.

Homogeneity of growth conditions within bioreactors was analyzed for five bioprocesses using two-way analysis of variance without repetition (ANOVA-2, $\alpha=0.05$ ). Eventually, $\log _{10}$ transformation was applied to achieve normal distribution of the parameters. The total variability was split into the three parameters: vertical positions, horizontal positions and residual error that includes undefined parameters such as handling or cultivation. For the analysis of the vertical position and for the horizontal position three times six coupons were evaluated.

\section{Repeatability of biofilm formation}

To test repeatability of biofilm formation five independent reactor experiments with $R$. mucilagino$s a$ were conducted. The biofilm samples were analyzed as previously described. ANOVA-2 with repetition was performed in order to determine the source of variation $(\alpha=0.05, n=18)$. The total variability was split into 'position' and 'repeatability', 'interaction' and residual error. Missing values ( $n=2$ per analysis) were replaced by the mean of the values measured at the same position on the five remaining holders. The Levene test was used to test the homoscedasticity of each single reactor experiment. In the case of variance equality, one-way ANOVA (ANOVA-1) was used to test average equality of each repetition. Under unequal variance conditions the results of the Brown-Forsythe test was considered.

\section{Results and discussion \\ Temporal development of biofilm formation and influence of roughness}

Temporal development of the yeast biofilms on smooth and rough PP surfaces was determined over a period of 2 weeks. In general as observed in CLSM micrographs (Figure 2) R. mucilaginosa colonized the rougher test coupons significantly better than the smooth ones, which is in accordance with previous studies that showed that microbial cells prefer rough surfaces for attachment (Quirynen et al. 1991; Muller et al. 2007) because cracks provide a protection from the shear forces (Zottola and Sasahara 1994; Palmer et al. 2007). The microscopic observations were confirmed by biofilm quantification (Figure 3). The number of living cells was significantly lower on smooth coupons compared to rough ones $\left(6 \times 10^{6}\right.$ vs $4 \times 10^{7} \mathrm{CFU}$ $\mathrm{cm}^{-2}$, respectively) and did not change significantly over the cultivation period (Figure 3a). The decrease in cell number and protein on the rough coupons observed on day 3 was due to sampling errors (ie additional immersion of the coupons in the cultivation medium as the coupon holder was blocked during sampling). The protein content on the smooth coupons remained stable over the entire cultivation period, whereas the median increased regularly on the rough coupons together with the variability (Figure $3 b$ ). The total amount of polysaccharides increased regularly together with the variability between samples. This increase was more marked for the rough coupons (Figure 3c). It was also observed that after day 6, when the rotation of the bioreactor was stopped for harvesting the coupons, parts of the biofilm detached from the rough coupons on the different holders.
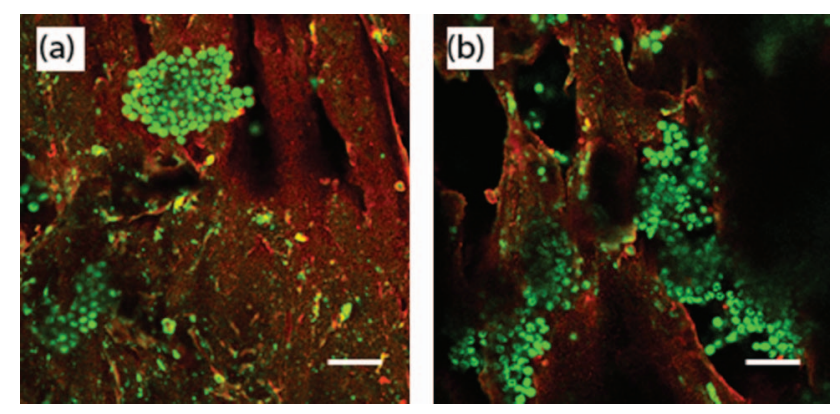

Figure 2. CLS micrographs of 1-day old biofilms on (a) smooth and (b) rough coupons. Two types of staining were used for EPS (ConcanavalinA, red) and cellular DNA (Syto $\mathrm{BC}$, green). The dark red signal originated from polypropylene. Most of the cells were gathered around small scratches that increased the overall surface area for attachment and also protected the cells from shear forces. Scale bar $=20 \mu \mathrm{m}$. 

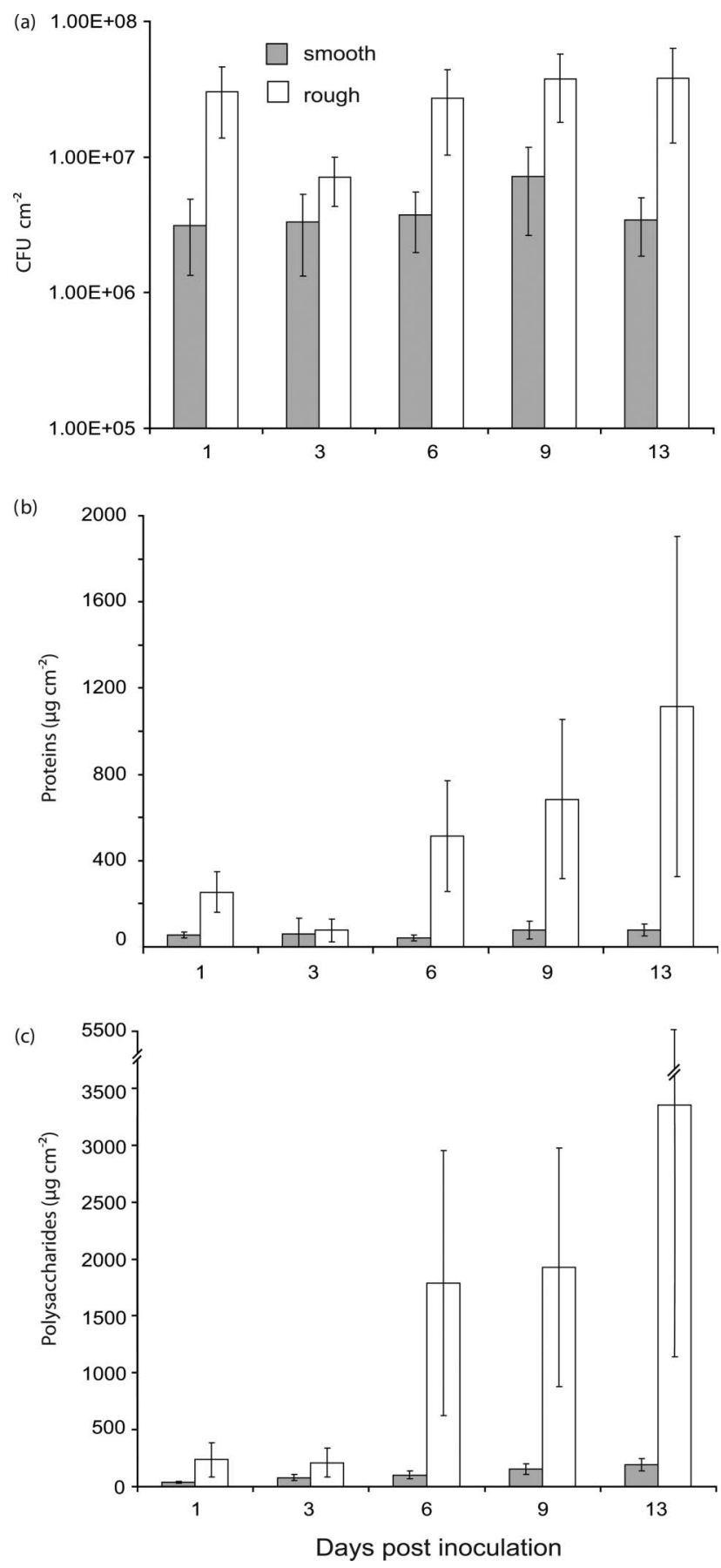

Figure 3. Time course experiment with $R$. mucilaginosa over 13 days post inoculation. Mean values and SD of (a) the colony forming units $(\mathrm{CFU}) \mathrm{cm}^{-2}$, (b) amount of proteins $\mathrm{cm}^{-2}$, and (c) amount of polysaccharides $\mathrm{cm}^{-2}$. 口: smooth coupons, $\square$ : rough coupons.

In order to achieve reproducible biofilm coverage on coupons, random events like erosion or sloughing should be limited. In the present experiments, sloughing was observed when the biofilm thickness increased and led to a higher flow resistance. This is a random event, which creates heterogeneity within the biofilm and does not lead to a reproducible biofilm (Lewandowski et al. 2004). Therefore, it was important to define the optimal surface and time period to harvest the produced biofilm before it started to detach. Figure 3 shows that reproducible biofilm coverage was achieved after 3 days and 6 days for the rough and smooth coupons, respectively. Further experiments were performed with the smooth coupons because the process of roughening increased the variability of the surface material. Prolongation of the bioprocess up to 6 days on the smooth coupons also offered the possibility of studying the different phases of biofilm development. Thus, in subsequent experiments biofilms were grown on smooth coupons for a period of 6 days.

\section{Spatial variability within the reactor}

Biofilms produced in five independent reactor experiments were harvested, sampled, and quantified on day 6. For all tested parameters in all experiments the largest source of variability was the vertical position (ie variability between the coupons located on the same sample holder) which was $24-83 \%$ within the reactor compared to the horizontal position (ie variability among the 6 sample holders) and $1-34 \%$ in a reactor (Table 1). However, the residual error contributed significantly to the overall variability $(10-74 \%)$.

The extent of the vertical gradient present in the bioreactor was illustrated for the protein content on the smooth (Figure 4) and rough coupons (see Figure 4, Supplementary data [Supplementary material is available via a multimedia link on the online article webpage]). Analysis of the biofilms on the smooth coupons with linear regression revealed that the vertical gradient was significant $(p<0.05)$ only for the reactor experiment No. 2 for protein (Figure 4), optical density and viable cell counts. For the rough coupons (see Figure 3, Supplementary data [Supplementary material is available via a multimedia link on the online article webpage]) no significant vertical gradients were detected. For the remaining experiments and for the rough coupons the vertical gradients were not significant (Figure 4).

The presence of horizontal and vertical gradients with respect to the thickness of the biofilm was reported for the rotating annular reactor (RAB reactor) (Gjaltema et al. 1994; Neu and Lawrence 1997). By contrast, CDC reactors appear to depict no significant spatial gradient (Goeres et al. 2005). One possible explanation is that the distance between the three coupons of the CDC reactor was relatively small (ca $5 \mathrm{~cm}$ ), whereas in the present system the whole 
Table 1. Summary of results for biofilm accumulation at day 6 post inoculation for smooth coupons and distribution of the source of variability within a reactor experiment.

\begin{tabular}{|c|c|c|c|c|c|c|}
\hline Parameter & $\begin{array}{l}\text { Components of total } \\
\text { variability }\end{array}$ & Exp. 1 & Exp. 2 & Exp.3 & Exp. 4 & Exp. 5 \\
\hline \multirow[t]{2}{*}{$\mathrm{OD}_{600}$} & Average value & 0.07 & 0.05 & 0.06 & 0.04 & 0.06 \\
\hline & $\mathrm{SD}$ & 0.02 & 0.03 & 0.03 & 0.02 & 0.02 \\
\hline \multirow{3}{*}{ Components of total variability } & Vertical (\%) & 42.7 & 30.0 & 82.6 & 27.1 & 25.1 \\
\hline & Horizontal ( $\%)$ & 15.9 & 4.7 & 7.9 & 1.3 & 1.1 \\
\hline & Residual error $(\%)$ & 41.4 & 65.4 & 9.5 & 71.6 & 73.9 \\
\hline \multirow[t]{2}{*}{ Proteins } & Average value $\left(\mu \mathrm{g} \mathrm{cm}^{-2}\right)$ & 85.0 & 87.1 & 77.7 & 57.0 & 82.6 \\
\hline & $\mathrm{SD}\left(\mu \mathrm{g} \mathrm{cm}^{-2}\right)$ & 23.1 & 43.2 & 36.9 & 38.1 & 24.7 \\
\hline \multirow{3}{*}{ Components of total variability } & Vertical $(\%)$ & 35.5 & 25.1 & 73.7 & 38.9 & 24.1 \\
\hline & Horizontal (\%) & 10.0 & 3.7 & 5.3 & 2.4 & 29.4 \\
\hline & Residual error (\%) & 54.5 & 71.2 & 21.1 & 58.7 & 46.5 \\
\hline \multirow{2}{*}{ Polysaccharides } & Average value $\left(\mu \mathrm{g} \mathrm{cm}^{-2}\right)$ & n. d. & 253.9 & 189.9 & 127.4 & 166.1 \\
\hline & $\mathrm{SD}\left(\mu \mathrm{g} \mathrm{cm}^{-2}\right)$ & n. d. & 175.5 & 99.1 & 38.7 & 69.2 \\
\hline \multirow[t]{3}{*}{ Components of total variability } & Vertical $(\%)$ & n. d. & 25.6 & 43.3 & 27.1 & 30.2 \\
\hline & Horizontal (\%) & n. d. & 4.0 & 8.0 & 6.3 & 30.4 \\
\hline & Residual error $(\%)$ & n. d. & 70.4 & 48.7 & 66.6 & 30.4 \\
\hline \multirow[t]{2}{*}{ CFU } & Average value (CFU $\mathrm{cm}^{-2}$ ) & n. d. & $1.0 \mathrm{E}+07$ & $5.1 \mathrm{E}+06$ & $4.8 \mathrm{E}+06$ & $6.1 \mathrm{E}+06$ \\
\hline & 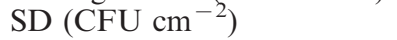 & n. d. & $9.8 \mathrm{E}+06$ & $3.3 \mathrm{E}+06$ & $2.7 \mathrm{E}+06$ & $4.2 \mathrm{E}+06$ \\
\hline \multirow{3}{*}{ Components of total variability } & Vertical (\%) & n. d. & 39.1 & 25.7 & 28.7 & 38.6 \\
\hline & Horizontal ( $\%)$ & n. d. & 5.4 & 33.9 & 11.8 & 2.2 \\
\hline & Residual error $(\%)$ & n. d. & 55.5 & 40.4 & 59.5 & 59.2 \\
\hline
\end{tabular}

Notes: The variance components are shown as percentages of the total variability; n. d. not determined.

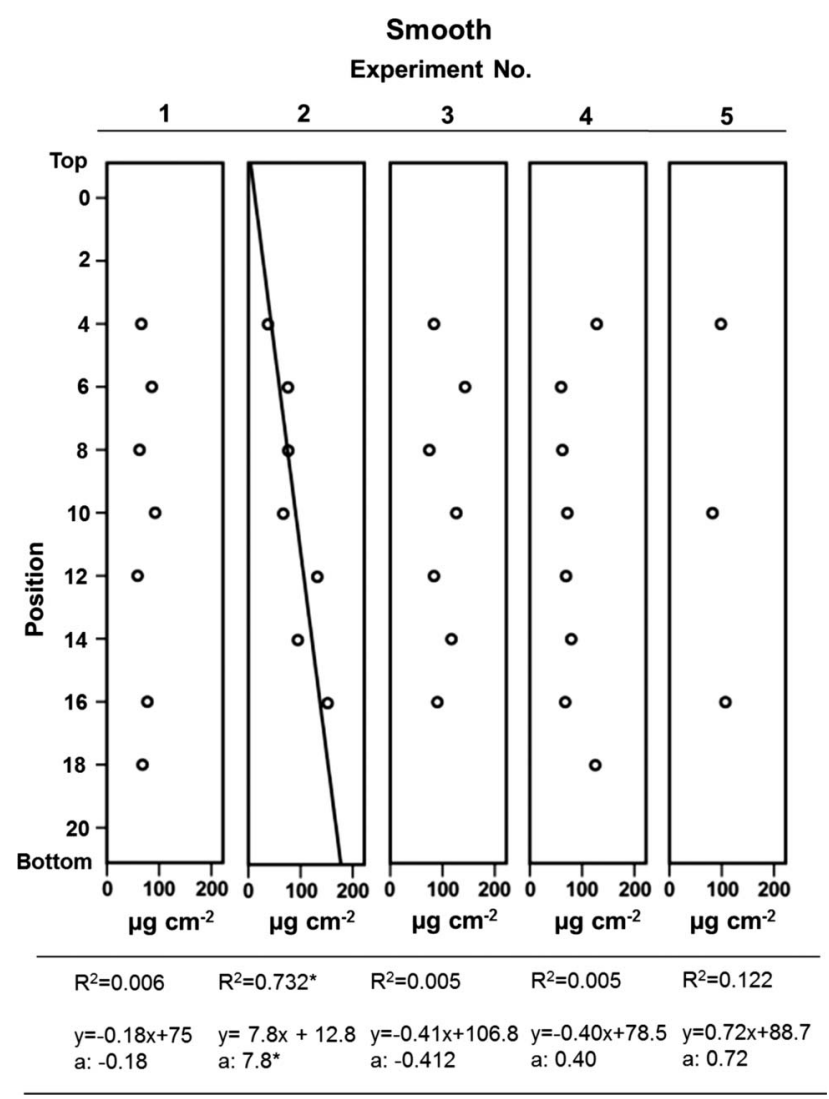

Figure 4. Vertical distribution from top to bottom of the protein amount for the five independent experiments on smooth coupons. Linear regression models with significance of $R^{2}$ and slope are indicated below $(\alpha=0.05),\left(^{*}\right)$ : significant. length of coupons in a row was $14 \mathrm{~cm}$ and in the RAB 10-15 cm (Lawrence et al. 2000; Milferstedt et al. 2006). A possibility to prevent sedimentation and the formation of thick biofilm at the bottom of the reactor would be to increase the shear flow or turbulence. In the present system the mixing was performed by the rotation of the cylinder holding the test coupons and by the flow caused by the external aeration loop.

\section{Repeatability of the bioprocess}

The amount of biofilm on the smooth coupons of each reactor experiment was quantified and displayed in Figure 5. The biofilm characterized by quantification of the amount of protein and polysaccharides, viable cell count, and optical density was similar from one experiment to another for both the smooth and rough coupons. The medians of the tested parameters $\left(\mathrm{OD}_{600}\right.$, protein and polysaccharide amount and viable cell count) varied between reactor experiments, but the values for the $n=4-5$ experiments always overlapped, none being completely different from another experiment. Also the ranges (minimal to maximal) of the values for the single reactor experiments were similar except for reactor No. 3 which also showed the largest variability between the coupons.

Taking all reactor experiments $(n=5)$ for the smooth coupons into account, the mean of the biofilm of each reactor experiment was statistically different from one run to another (eg ANOVA-1 for polysaccharide amount $p$ value: 0.008) except for the 

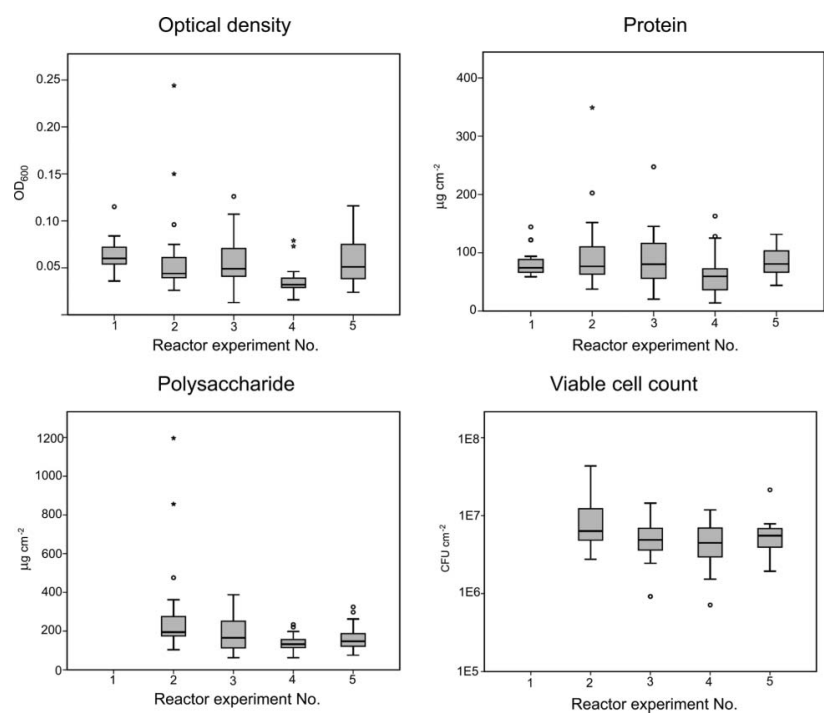

Figure 5. Box plot analysis of biofilm formed on smooth coupons. For 4-5 independent experiments $\mathrm{OD}_{600}$, protein, polysaccharide, and viable cell counts were quantified. Whiskers: maximal and minimal values, bold line: median, O: outlier, *: extreme values.

protein amount ( $p$ value: 0.066 ). The difference from the minimal mean to the maximal mean on the smooth coupons of the five independent reactor experiments was $45 \%$ for OD, $38 \%$ for protein, $52 \%$ for polysaccharide and $50 \%$ for CFU. The reactor experiment which showed the largest difference was reactor experiment No. 4 (Figure 5). For protein and OD the differences in the remaining reactor experiments did not exceed $20 \%$, while for polysaccharide and CFU the minimal difference was still around $35 \%$ and $42 \%$, respectively. The larger differences for polysaccharide and CFU could be mainly the result of the several handling and dilution steps of the analytical method.

Interestingly, the distribution of the medians and the single values were larger for the rough coupons than for the smooth coupons, indicating heterogeneity of biofilm formation probably due to sloughing (Figure 6). It can also be assumed that due to the increased surface area (Katsikogianni and Missirlis 2004; Palmer et al. 2007) and attachment possibilities the cells could establish biofilm faster on the rough coupons. This could consequently lead to earlier sloughing events. To compare the mean of the smooth and the rough coupons a $T$-test was conducted. It revealed that the biofilm was statistically different $(p<0.000)$ for the smooth and rough coupons.

The variability was analyzed using ANOVA-2 with 'repeatability' (between experiments) and 'position' (in-between experiments) as sources of variability (Table 2). A main source of variability was 'repeatability' ranging from $13-21 \%$ (smooth) and $12-34 \%$

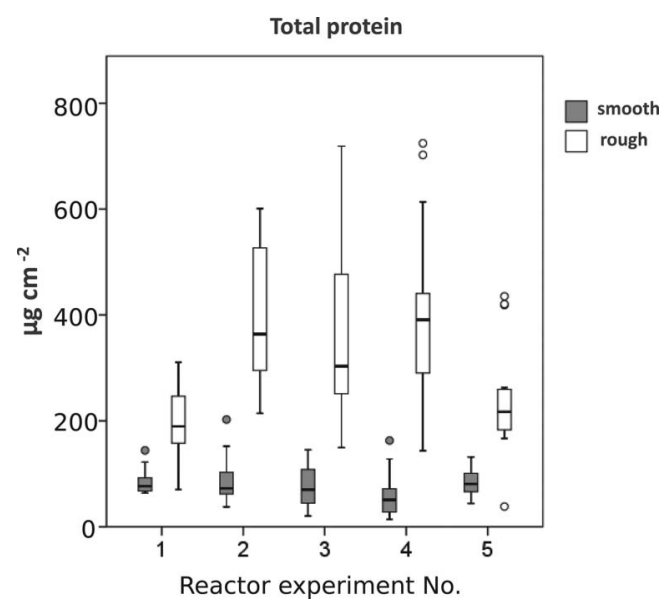

Figure 6. Box plot of total protein content of biofilm. Smooth ( $\square)$ and rough PP $(\square)$ coupons $\left(\mu \mathrm{g} \mathrm{cm}^{-2}\right)$ were used for five independent experiments with $(n=18-23)$ coupons per reactor. Whiskers: maximal and minimal values, bold line: median, $\mathrm{O}$ : outlier, *: extreme values.

Table 2. ANOVA-2 of results for biofilm accumulation at day 6 post inoculation for smooth and rough coupons. All parameters were $\log _{10}$ transformed.

\begin{tabular}{lrrrr}
\hline & OD $_{600}$ & Proteins & Polysaccharides & CFU \\
\hline Smooth coupons & & & & \\
Repeatability (\%) & 21.2 & 17.9 & 18.9 & 13.2 \\
Position (\%) & 2.6 & 4.4 & 4.4 & 9.2 \\
Interaction (\%) & 3.7 & 2.2 & 5.9 & 2.9 \\
Residual error (\%) & 72.5 & 75.5 & 70.9 & 74.6 \\
$\quad$ (handling, etc.) & & & & \\
Rough coupons & & & & \\
Repeatability (\%) & 12.1 & 34.3 & 18.8 & 21.6 \\
Position (\%) & 2.2 & 2.9 & 6.7 & 4.1 \\
Interaction (\%) & 12.2 & 8.4 & 13.3 & 2.4 \\
Residual error (\%) & 73.6 & 54.4 & 61.2 & 71.9 \\
$\quad$ (handling, etc.) & & & & \\
\hline
\end{tabular}

Note: The variance components are shown as percentages of the total variability.

(rough) of the total variability. The parameter "position' had less influence on the total variability, ranging from $3-4 \%$ (smooth) and $2-7 \%$ (rough) of the total variability. However, the main source of variability was a 'residual error' that could be due to other undefined parameters such as harvesting, handling or the method of measurement that represented $71-75 \%$ and $54-74 \%$ for the smooth and rough coupons, respectively.

Pitts et al. (2001) reported that the amongexperiment variability contributed the least to the total variability. In experiments without chlorine treatment the within-reactor variability was about 60 and $73 \%$, respectively, while the among-reactor variability was 40 and $27 \%$. In our study most of the variation from 
one to another reactor experiment was observed to come from the remaining variability (residual error)/ parameters (eg handling). Therefore finding the most appropriate method for biofilm quantification resulting in smaller residual errors is crucial for testing repeatability.

\section{Influence of the supporting material}

\section{Wettability and surface composition}

Plasma treatments were used to investigate the influence of wettability and surface composition on fouling. Non-treated PP coupons (rough, smooth and dcPP) had water contact angles of $c a 90^{\circ}$. Plasma treatments led to a similarly significant increase in hydrophilicity that remained after both autoclaving and rinsing the SDB films (Table 3). The coupons were exposed to $30 \%$ SDB to simulate the conditions within the reactor as previously described in the in situ sterilization protocol. All surfaces contained an elevated number of $\mathrm{N}$ and $\mathrm{O}$ atoms. The surface composition remained stable after the sterilization process except for a few changes in the amount of $\mathrm{O}$ and $\mathrm{N}$ atoms (Table 4). To evaluate the attachment of cells and further biofilm growth on the plasma treated surfaces, the coupons were harvested after 1, 3 and 6 days. The initial cell attachment as well as the early fouling (day 3) were similar for all plasma treated surfaces (Figure 7). After 6 days some differences could be observed, eg $\mathrm{Ar} / \mathrm{O}_{2}$ treated coupons were significantly less fouled than $\mathrm{CO}_{2} / \mathrm{C}_{2} \mathrm{H}_{4}$ plasma treated surfaces (Figure 7). $\mathrm{NH}_{3} / \mathrm{C}_{2} \mathrm{H}_{4}$ based polymers have already been described to enhance cell adhesion due to the high content of amino groups (Truica-Marasescu and Wertheimer 2008). For example, the attachment of mouse fibroblasts was significantly increased on $\mathrm{NH}_{3} /$ $\mathrm{C}_{2} \mathrm{H}_{4}$ treated poly(L-lactide) material compared to untreated material (Wan et al. 2003). Similarly, oxygen-based functional groups have been reported to enhance cell attachment (Wei et al. 2007) under

Table 3. Static water contact angle measurement of plasma treated coupons before and after autoclaving $(n=3)$.

\begin{tabular}{lcccc}
\hline Treatment & Ratio & $\begin{array}{c}\text { Before } \\
\text { autoclaving }\end{array}$ & $\begin{array}{c}\text { Autoclaved } \\
\text { in SDB }\end{array}$ & $\begin{array}{c}\text { Autoclaved } \\
\text { in SDB } \\
\text { and rinsed }\end{array}$ \\
\hline None & - & $\sim 90^{\circ}$ & n. d. & n. d. \\
$\mathrm{CO}_{2} / \mathrm{C}_{2} \mathrm{H}_{4}$ & $2: 1$ & $55^{\circ} \pm 1^{\circ}$ & $3^{\circ} \pm 3^{\circ}$ & $41^{\circ} \pm 4^{\circ}$ \\
$\mathrm{CO}_{2} / \mathrm{C}_{2} \mathrm{H}_{4}$ & $6: 1$ & $54^{\circ} \pm 3^{\circ}$ & Flat film & $37^{\circ} \pm 3^{\circ}$ \\
$\mathrm{NH}_{3} / \mathrm{C}_{2} \mathrm{H}_{4}$ & $1: 1$ & $53^{\circ} \pm 2^{\circ}$ & Flat film & $36^{\circ} \pm 9^{\circ}$ \\
$\mathrm{NH}_{3} / \mathrm{C}_{2} \mathrm{H}_{4}$ & $2: 1$ & $54^{\circ} \pm 2^{\circ}$ & Flat film & $31^{\circ} \pm 5^{\circ}$ \\
$\mathrm{Ar} / \mathrm{O}_{2}$ & - & $61^{\circ} \pm 2^{\circ}$ & $31^{\circ} \pm 4^{\circ}$ & $51^{\circ} \pm 1^{\circ}$ \\
$\mathrm{N}_{2}$ & - & $53^{\circ} \pm 2^{\circ}$ & $16^{\circ} \pm 9^{\circ}$ & $43^{\circ} \pm 4^{\circ}$ \\
\hline
\end{tabular}

Note: n. d.: Not determined. static or low shear conditions. In the present experiments, these two types of plasma-based surface modifications did not enhance the attachment of cells although the surfaces were highly hydrophilic.

The influence of shear forces can be excluded because the smooth and roughened coupons showed significant biofilm formation under identical growth conditions. It seems that cell adhesion is enhanced only in the case of mammalian cells, which agrees with other reports where surfaces were modified using plasma polymerization techniques. For bacterial cells, the plasma-coating technique was applied to incorporate antimicrobials and other toxic compounds to prevent microbial attachment (Jansen and Kohnen 1995; Sen et al. 2009).

\section{Relevance of the study}

Standardized biofilms are essential to develop test systems to assess the efficacy of the methods of biofilm removal. Currently, limited data are available

Table 4. X-ray photoelectron spectroscopy measurements of differently treated dcPP coupons before and after autoclaving.

\begin{tabular}{|c|c|c|c|c|c|c|}
\hline \multirow[b]{3}{*}{ Treatment } & \multirow{2}{*}{\multicolumn{3}{|c|}{$\begin{array}{c}\text { Before } \\
\text { autoclaving } \\
\text { Relative atomic } \\
\text { composition } \\
(\%)\end{array}$}} & \multicolumn{3}{|c|}{ After autoclaving $^{\mathrm{a}}$} \\
\hline & & & & \multicolumn{3}{|c|}{$\begin{array}{l}\text { Relative atomic } \\
\text { composition }(\%)\end{array}$} \\
\hline & {$[\mathrm{C}]$} & {$[\mathrm{O}]$} & {$[\mathrm{N}]$} & {$[\mathrm{C}]$} & {$[\mathrm{O}]$} & {$[\mathrm{N}]$} \\
\hline None & 98 & 2 & 0 & n. d. & n. d. & n. d. \\
\hline $\mathrm{CO}_{2} / \mathrm{C}_{2} \mathrm{H}_{4}(2: 1)$ & 79 & 20 & 1 & 75 & 19 & 6 \\
\hline $\mathrm{CO}_{2} / \mathrm{C}_{2} \mathrm{H}_{4}(6: 1)$ & 78 & 22 & 0 & 76 & 19 & 5 \\
\hline $\mathrm{NH}_{3} / \mathrm{C}_{2} \mathrm{H}_{4}(1: 1)$ & 70 & 14 & 16 & 70 & 17 & 12 \\
\hline $\mathrm{NH}_{3} / \mathrm{C}_{2} \mathrm{H}_{4}(2: 1)$ & 72 & 13 & 15 & 71 & 16 & 13 \\
\hline $\mathrm{Ar} / \mathrm{O}_{2}$ & 82 & 15 & 3 & 83 & 12 & 5 \\
\hline $\mathrm{N}_{2}$ & 75 & 11 & 14 & 80 & 12 & 8 \\
\hline
\end{tabular}

Notes: ${ }^{a}$ In presence of $30 \%$ Sabouraud dextrose broth and rinsing with nanopure water; $n$. d.: not determined.

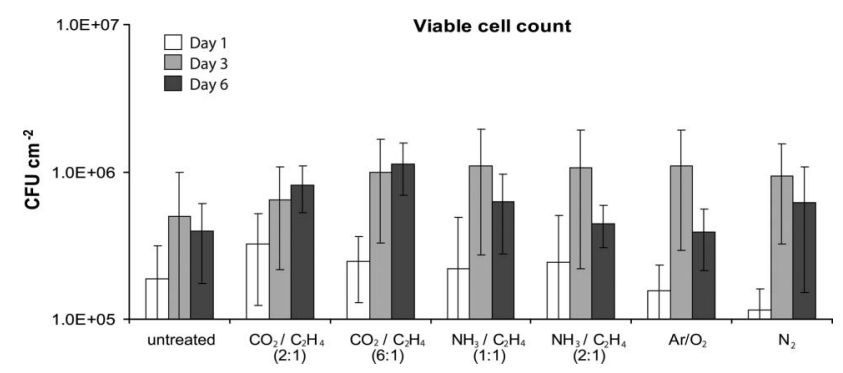

Figure 7. Cell attachment and biofilm formation by $R$. mucilaginosa on dye-cast rough PP coupons with differently treated plasma-based modifications. Sampling occurred after 1,3 , and 6 days post inoculation with $n=4$ coupons per treatment. 
regarding yeast biofilms and these studies have focussed on C. albicans. A 'new', up-coming group of opportunistic pathogens are Rhodotorula species that have caused fungemia in neonates and other immunocompromised individuals (Duggal et al. 2011).

In this study a reactor system was presented that allowed growth, sampling and quantification of $R$. mucilaginosa biofilms at different stages of development. This bioprocess made use of a commercially available laboratory fermenter with a custom-made rotating cylinder harbouring holders for test coupons. The bioreactor combined features of the CDC biofilm reactor (Donlan et al. 2002; Goeres et al. 2005) and the RAB reactor (Lawrence et al. 2000) and presented distinct advantages over other systems such as continuous exchange of growth medium or the possibility to conduct in situ sterilization, ie the cultivation medium together with the test coupons can be sterilized within the reactor. In situ sterilization of the medium reduced the risk of contamination. Due to integrated temperature and $\mathrm{pH}$ controls, the overall handling of the system is facilitated and repeatability of the bioprocess increased. In contrast to the CDC biofilm reactor and the $\mathrm{RAB}$, this design allows a relatively large sample number of up to 120 coupons per bioprocess. This leaves more possibilities for designing of experiments, eg testing cell attachment onto different types of materials (silicone to mimic medical catheters or stainless steel for food industrial purposes) or surface treatments during a single experiment. A further advantage of this system is the ability to follow the development of biofilm formation by sampling and analysis of the biofilms at different time points.

The development of a standardized model biofilm enables the determination of cleaning, removal, and killing efficiency of mechanical procedures and chemical agents (Gattlen et al. 2010). With the possibility of sampling the biofilms at any phase of their development, antimicrobial studies can be performed with young, initially mature or mature biofilms. The antimicrobial action or efficacy of other chemical agents can be determined and their concentrationdosage effect can be adjusted against yeast or specifically against $R$. mucilaginosa.

Treatment with antimicrobial agents has to result in an at least a 4-log reduction of cell number for a fungicidal activity (DIN EN 1275; European Committee for Standardisation 1997), while $>5$-log reduction of bacterial CFU is required (DIN EN 1040; German Institute for Standardization 1997). Similarly, a 4-log reduction in cell numbers may be adequate for biofilm removal tests even though no requirements for these tests are currently available in international standards. With the test system described herein, biofilms of up to
$10^{7}$ cells $\mathrm{cm}^{-2}$ could be grown after 6 days. Considering that the detection limit for $\mathrm{CFU}$ is about 10 cells $\mathrm{cm}^{-2}$, the biofilm produced should consist of $>10^{6}$ yeast cells $\mathrm{cm}^{-2}$ in order to enable the determination of up to $5-\log$ a removal efficiency.

\section{Conclusions}

The aim of this study was to produce a model biofilm with $R$. mucilaginosa for testing the removal efficiency of washing devices (eg household washing machines). A model was developed to form biofilms that were stable with a sufficient amount of viable cells, protein and polysaccharides. In this study yeast biofilms were grown in a repeatable manner in a modified bench-top bioreactor after 6 days. Yeast biofilms grown on smooth PP surfaces were similar in terms of the amount of organic matter and viable cell number in all five independent reactor experiments. Moreover, it was demonstrated that surface modification (roughening) increased the surface area for attachment but concomitantly also increased the variability of all measured parameters compared to the smooth coupons. This study also demonstrated that neither roughness alone nor the surface hydrophilicity is decisive for cell attachment and consequent biofilm formation by $R$. mucilaginosa. However, for yeast biofilms and their cultivation, more fundamental knowledge needs to be acquired. In particular, yeast cells do not have completely identical biofilm formation behaviour as bacteria. Also cell attachment, cell-cell communication and expression profile during biofilm formation are still largely unknown. Therefore, the relevance and benefit of yeast biofilms need to be further explored.

\section{Acknowledgements}

This work has been financially supported by the Swiss Commission for Technology and Innovation (CTI project 9075.1PFLS-LS). Special thanks go to Max Keller, Joerg Gschwend, and the whole team of Empa's machine shop for the construction of the cylinder for the biofilm reactor. The authors also thank Kathrin Grieder, Aline Hunziker, Bettina Lanz and Monika Braegger for the microbiological analysis, Barbara Hanselmann for the plasma treatments, Patrick Rupper for XPS analyses, Miele and Treff AG for providing polypropylene material, and Bruno Wampfler for fruitful discussions about the manuscript.

\section{References}

Bloss R, Kampf G. 2004. Test models to determine cleaning efficacy with different types of bioburden and its clinical correlation. J Hosp Infect 56:44-48.

Brugnoni LI, Lozano JE, Cubitto MA. 2007. Potential of yeast isolated from apple juice to adhere to stainless steel surfaces in the apple juice processing industry. Food Res Int 40:332-340. 
Busscher HJ, de Boer CE, Verkerke GJ, Kalicharan R, Schutte HK, van der Mei HC. 1994. In vitro ingrowth of yeasts into medical grade silicone rubber. Int Biodeterior Biodegr 33:383-390.

Chambers LD, Stokes KR, Walsh FC, Wood RJK. 2006. Modern approaches to marine antifouling coatings. Surf Coat Technol 201:3642-3652.

Chandra J, Kuhn DM, Mukherjee PK, Hoyer LL, McCormick T, Ghannoum MA. 2001. Biofilm formation by the fungal pathogen Candida albicans: development, architecture, and drug resistance. J Bacteriol 183:5385-5394.

Chen X, Stewart PS. 2000. Biofilm removal caused by chemical treatments. Water Res 34:4229-4233.

Donlan R, Murga R, Carpenter J, Brown E, Besser R, Fields B. 2002. Monochloramine disinfection of biofilmassociated Legionella pneumophila in a potable water model system. In: Marre R, Abu Kwaik Y, Bartlett C, Cianciotto NP, Fields BS, Frosch M, Hacker J, Luck PC, editors. Washington DC: ASM Press. p. 406410.

Douglas LJ. 2002. Medical importance of biofilms in Candida infections. Rev Iberoam Micol 19:139-143.

Dubois M, Gilles KA, Hamilton JK, Rebers PA, Smith F. 1956. Colorimetric method for determination of sugars and related substances. Anal Chem 28:350-356.

Duggal S, Jain H, Tyagi A, Sharma A, Chugh TD. 2011. Rhodotorula fungemia: two cases and a brief review. Med Mycol 1-4. Available from: http://informahealthcare. $\mathrm{com} /$ action $/$ doSearch? search Text=duggal\&type $=$ simple \&filter $=$ multiple\&categoryId $=40053453$.

Elvers KT, Leeming K, Moore CP, Lappin-Scott HM. 1998. Bacterial-fungal biofilms in flowing water photo-processing tanks. J Appl Microbiol 84:607-618.

European Committee for Standardisation. 1997. European standard EN 1275: chemical disinfectants and antiseptics - quantitative suspension test for the evaluation of basic fungicidal or basic yeasticidal activity of chemical disinfectants and antiseptics - test method and requirements (phase 1). Brussels (Belgium): European Committee for Standardisation.

Flemming HC, Wingender J. 2010. The biofilm matrix. Nat Rev Microbiol 8:623-633.

Gattlen J, Amberg C, Zinn M, Mauclaire L. 2010. Biofilms isolated from washing machines from three continents and their tolerance to a standard detergent. Biofouling 26:873-882.

German Institute for Standardization. 1997. Chemical disinfectants and antiseptics - quantitative suspension test for the evaluation of basic bactericidal activity of chemical disinfectants and antiseptics - test method and requirements (phase 1). Berlin (Germany): DIN German Institute for Standardization.

Gjaltema A, Arts PAM, van Loosdrecht MCM, Kuenen JG, Heijnen JJ. 1994. Heterogeneity of biofilms in rotating annular reactors - occurrence, structure, and consequences. Biotechnol Bioeng 44:194-204.

Goeres DM, Loetterle LR, Hamilton MA, Murga R, Kirby DW, Donlan RM. 2005. Statistical assessment of a laboratory method for growing biofilms. Microbiology 151:757-762.

Hadi R, Vickery K, Deva A, Charlton T. 2010. Biofilm removal by medical device cleaners: comparison of two bioreactor detection assays. J Hosp Infect 74:160-167.

Hamilton MA. 2002. Testing antimicrobials against biofilm bacteria. J AOAC Int 85:479-485.
Harding MW, Marques LLR, Howard RJ, Olson ME. 2009. Can filamentous fungi form biofilms? Trends Microbiol 17:475-480.

Hegemann D, Hossain MM, Balazs DJ. 2007. Nanostructured plasma coatings to obtain multifunctional textile surfaces. Prog Org Coat 58:237-240.

Hentzer M, Teitzel GM, Balzer GJ, Heydorn A, Molin S, Givskov M, Parsek MR. 2001. Alginate overproduction affects Pseudomonas aeruginosa biofilm structure and function. J Bacteriol 183:5395-5401.

Honraet K, Goetghebeur E, Nelis HJ. 2005. Comparison of three assays for the quantification of Candida biomass in suspension and CDC reactor grown biofilms. J Microbiol Methods 63:287-295.

Hossain MM, Herrmann AS, Hegemann D. 2007. Plasma deposition of amine-embedded nanoporous ultrathin films on polyester enables substrate independent surface dyeing. Plasma Process Polym 4:1068-1074.

Jansen B, Kohnen W. 1995. Prevention of biofilm formation by polymer modification. J Ind Microbiol Biotechnol 15:391-396.

Jenkinson HF, Douglas LJ. 2002. Interactions between Candida species and bacteria in mixed infections. In: Brogden KA, Guthmiller JM, editors. Polymicrobial diseases. Washington DC: ASM Press. p. 357-373.

Katsikogianni M, Missirlis YF. 2004. Concise review of mechanisms of bacterial adhesion to biomaterials and of techniques used in estimating bacterial interactions. Eur Cell Mater 8:37-57.

Kharazmi A, Giwercman B, Hoiby N. 1999. Robbins device in biofilm research. Methods Enzymol 310:207-215.

Koerner E, Fortunato G, Hegemann D. 2009. Influence of RF plasma reactor setup on carboxylated hydrocarbon coatings. Plasma Process Polym 6:119-125.

Kronlof J, Haikara A. 1991. Contamination of immobilized yeast bioreactors. J Inst Brew 97:375-380.

Kumar CG, Anand SK. 1998. Significance of microbial biofilms in food industry: a review. Int J Food Microbiol 42:9-27.

Lawrence JR, Swerhone GDW, Neu TR. 2000. A simple rotating annular reactor for replicated biofilm studies. $\mathbf{J}$ Microbiol Methods 42:215-224.

Lewandowski Z, Beyenal H, Stookey D. 2004. Reproducibility of biofilm processes and the meaning of steady state in biofilm reactors. Water Sci Technol 49:359-364.

Lyon DY, Brown D, Sundstrom ER, Alvarez PJJ. 2008. Assessing the antibiofouling potential of a fullerenecoated surface. Int Biodeterior Biodegr 62:475-478.

Milferstedt K, Pons MN, Morgenroth E. 2006. Optical method for long-term and large-scale monitoring of spatial biofilm development. Biotechnol Bioeng 94:773-782.

Muller R, Groger G, Hiller KA, Schmalz G, Ruhl S. 2007. Fluorescence-based bacterial overlay method for simultaneous in situ quantification of surface-attached bacteria. Appl Environ Microbiol 73:2653-2660.

Munk S, Johansen C, Stahnke LH, Adler-Nissen J. 2001. Microbial survival and odor in laundry. J Surf Deterg 4:385-394.

Neu TR, Lawrence JR. 1997. Development and structure of microbial biofilms in river water studied by confocal laser scanning microscopy. FEMS Microbiol Ecol 24:11-25.

Palmer J, Flint S, Brooks J. 2007. Bacterial cell attachment, the beginning of a biofilm. J Ind Microbiol Biotechnol 34:577-588.

Palmer RJ, Jr. 1999. Microscopy flowcells: perfusion chambers for real-time study of biofilms. Methods Enzymol 310:160-166. 
Pitts B, Hamilton MA, Zelver N, Stewart PS. 2003. A microtiter-plate screening method for biofilm disinfection and removal. J Microbiol Methods 54:269-276.

Pitts B, Willse A, McFeters GA, Hamilton MA, Zelver N, Stewart PS. 2001. A repeatable laboratory method for testing the efficacy of biocides against toilet bowl biofilms. J Appl Microbiol 91:110-117.

Quirynen M, Marechal M, van Steenberghe D, Busscher HJ, van der Mei HC. 1991. The bacterial colonization of intra-oral hard surfaces in vivo: influence of surface free energy and surface roughness. Biofouling 4:187-198.

Ramage G, Vande Walle K, Wickes BL, Lopez-Ribot JL. 2001. Standardized method for in vitro antifungal susceptibility testing of Candida albicans biofilms. Antimicrob Agents Chemother 45:2475-2479.

Rambali B, Fernandez JA, Van Nuffel L, Woestenborghs F, Baert L, Massart DL, Odds FC. 2001. Susceptibility testing of pathogenic fungi with itraconazole: a process analysis of test variables. J Antimicrob Chemother 48:163-177.

Rayner J, Veeh R, Flood J. 2004. Prevalence of microbial biofilms on selected fresh produce and household surfaces. Int J Food Microbiol 95:29-39.

Reynolds TB, Fink GR. 2001. Bakers' yeast, a model for fungal biofilm formation. Science 291:878-881.

Saithong P, Nakamura T, Shima J. 2009. Prevention of bacterial contamination using acetate-tolerant Schizosaccharomyces pombe during bioethanol production from molasses. J Biosci Bioeng 108:216-219.

Sen Y, Bagci U, Gulec HA, Mutlu M. 2009. Modification of food-contacting surfaces by plasma polymerization technique: reducing the biofouling of microorganisms on stainless steel surface. Food Bioprocess Technol. Available from: http://www.springerlink.com/content/ k1rm363w774138w2/ doi:10.1007/s11947-009-0248-1.
Shi X, Zhu X. 2009. Biofilm formation and food safety in food industries. Trends Food Sci Technol 20:407-413.

Sutherland IA. 2001. The biofilm matrix - an immobilized but dynamic microbial environment. Trends Microbiol 9:222-227.

Truica-Marasescu F, Wertheimer MR. 2008. Vacuum-ultraviolet photopolymerisation of amine-rich thin films. Macromol Chem Phys 209:1043-1049.

Vopalenska I, Stovicek V, Janderova B, Vachova L, Palkova Z. 2010. Role of distinct dimorphic transitions in territory colonizing and formation of yeast colony architecture. Environ Microbiol 12:264-277.

Wan YQ, Yang J, Yang JL, Bei JZ, Wang SG. 2003. Cell adhesion on gaseous plasma modified poly-(L-lactide) surface under shear stress field. Biomaterials 24:37573764.

Webb JS, Nixon M, Eastwood IM, Greenhalgh M, Robson GD, Handley PS. 2000. Fungal colonization and biodeterioration of plasticized polyvinyl chloride. Appl Environ Microbiol 66:3194-3200.

Wei J, Yoshinari M, Takemoto S, Hattori M, Kawada E, Liu B, Oda Y. 2007. Adhesion of mouse fibroblasts on hexamethyldisiloxane surfaces with wide range of wettability. J Biomed Mater Res B Appl Biomater 81:66-75.

Zottola EA, Sasahara KC. 1994. Microbial biofilms in the food-processing industry - should they be a concern. Int J Food Microbiol 23:125-148. 